Zagadnienia Rodzajów Literackich, LX, z. 2

PL ISSN 0084-4446

DOI: $10.26485 / Z R L / 2017 / 60.2 / 1$

Naomi Segal

University of London*

\title{
The Principles, Pleasures and Realities of Translating Psychoanalysis
}

\begin{abstract}
Are all translators murderers, pests or parasites? Are they humble or the spokespersons of a community? Are they trustworthy or traitors, or even 'faithful bigamists'? And do translations have to be beautiful or faithful, never both? Might translation be a feminine/ feminised activity because most translators are women, or because the target-language is maternal or because it embodies the paradox of the multi-skilled serving the monoskilled? The second half of this essay focuses on the translation of psychoanalysis, especially Strachey's brilliant yet much-criticised translation of Freud.
\end{abstract}


* Visiting Professor in French \& German Studies, Dept of Cultures \& Languages, School of Arts, Birkbeck, University of London 43 Gordon Square, London WC1H 0PD, UK e-mail:n.segal@bbk.ac.uk 
A few months ago, after forty years researching in modern languages (comparative literary and cultural studies) ${ }^{1}$, I published my first book-length translation - The Skin-ego, from Didier Anzieu's Le Moi-peau (1995) 2. This essay is a meditation on the world of translation into which this has introduced me. It is divided into two sections: first, a broad-brush survey of ways of looking at the process and product of translation today; and second, a tour through the history and debates on translation of psychoanalysis, with a particular focus on the rendition of Freud into English.

I will not be talking about the use, which is getting increasingly common nowadays, of the term 'translation' to mean things other than the rendering of a piece of language into another language. This broader metaphoric use has a noble history, of course, as witness Quince on seeing Bottom as an ass: 'Bless thee, Bottom, bless thee. Thou art translated' (Shakespeare 1951: 208); and shortly before writing this I came across a discussion of how 'the psychoanalyst translates the unconscious' (Birksted-Breen 2010: 687) — true, of course; the idea originates with Freud - and, used more fancifully, a sentence stating that in June 1938 'Freud himself has just been translated to London, and is finally ready for Moses and Monotheism (...) to be translated into English' (Phillips 2007: 5). I will be focusing on the second use of the word in that sentence and not the first.

Studies of translation, and 'Translator's prefaces', tend to open with ringing declarations. Here are nine examples, in no particular order.

$1 \quad$ NB Unless otherwise noted, all translations from French or German are my own.

Like everyone in this field, I have learned, taught and practised translation in the context of studying, teaching and researching literature written in languages other than my native language. I have also created and run a series of four courses for native Anglophones taught by professional literary translators of fifteen contemporary languages.

2 Didier Anzieu (1923-1999) was a French psychoanalyst and theorist whose work brings the body back to the centre of psychoanalytic enquiry. He was the author of twenty books and numerous articles, on areas ranging from the psychology of groups and psychodrama to theories of creativity and thought; he also published short stories, literary criticism, a drama, a book of cartoons and a pseudonymous study of May '68 written from the heart of Nanterre. His major work is Le Moi-peau [The Skin-ego] $(1985,1995)$. The replacement child of a replacement child, he was analysed by Lacan, not knowing at the time that the latter had treated his mother. My interest in him goes back nearly twenty years, deriving from my research interest in the body and representation, and is focused not least on the potential of a leading organ, the skin, which is equally the province of both sexes. 
All translation is to some extent misrepresentation. (Adey Huish 2002: XXVIII)

Most translators try to make themselves invisible. (Underwood 2005: XLIII)

Translation is always interpretation. (Birksted-Breen 2010: 687)

Translation involves the murder of the original. (Forrester 1990: 99)

...the translator is usually a shy character. Because of his humility, he has chosen such an insignificant occupation. (José Ortega y Gasset in Venuti 2000: 50)

The great pest of speech is frequency of translation. (Samuel Johnson, cited by Rand in Graham 1985: 82)

The writer who is content to destroy is on a plane with the writer who is content to translate. Both are parasites. (Wallace Stevens, cited by Rand in Graham 1985: 83)

'Translatorship' amounts first and foremost to being able to play a social role, to fulfil a function allotted by a community'. (Gideon Toury in Venuti 2000: 198)

All translation (...) starts with an act of trust. (George Steiner in Venuti 2000: 186)

So: are all translators murderers, pests or parasites? Are they humble or the spokespersons of a community? Are they trustworthy or traitors? This brief trawl of six texts on the theory and practice of translation illustrates the strength and variety of viewpoints on the action and the agent.

And here are two apocryphal — and untranslatable — sayings about translation, which I shall translate nevertheless: the Italian Traduttore, traditore, which may be rendered into English as 'translator, traitor' (this just about captures the sound-pattern as well as the sense); and the French La traduction est comme la femme: si elle est belle elle n'est pas fidèle et si elle est fidele elle n'est pas belle. For the latter, I offer 'Translations are like women: if they are beautiful they are not faithful and if they are faithful they are not beautiful' - because English lacks the gender-use as well as the rhyme that makes this neat (if sexist) in French, I choose plural nouns rather than singular.

We shall return to my first list of characterisations of the translator presently but first let us consider a few conceptual pairs that preoccupy theorists and practitioners alike.

\section{Beauty or fidelity}

As many theorists have noted, these Italian and French sayings exemplify the popular contrast between the faithful and the beautiful in translations. The sexism is no coincidence, though it maps curiously onto the fact that in these two aphorisms the translator is male while the translation is female. This is despite the general view that the 'humble' or 'invisible' role of translator is most often taken by women while the source-text authors are men, on the general assumption that production is the real thing and reproduction is not. In a lively blog published on St Valentine's Day, Claire Pacial analyses uses of misogynistic terms, like 'le viol fécond' [fertile rape], which links the fertility of translation (into 'la langue maternelle' [the mother tongue]) to the violence of a penetrative act that divides the men from the boys (Pacial 2014: n. p.). Less hecticly, more wittily, Barbara Johnson makes a comment that deserves a full quotation: 
While the value of the notion of fidelity is at an all-time high in the audiovisual media, its stocks are considerably lower in the domains of marital mores and theories of translation. It almost seems as though the stereo, the Betamax, and the Xerox have taken over the duty of faithfulness in reproduction, leaving the texts and the sexes with nothing to do but disseminate. This is perhaps the inevitable result of the intersection between contemporary psychoanalytical, Marxist, and philosophical critiques of consciousness, on the one hand, and modern technology, on the other. When computers, automated assembly lines, and photocopiers advantageously replace human memories and hands, and when language, ideology, and the unconscious are aptly compared to machines of which we are the puppets, it is difficult to know what to do with that defensive excrescence called consciousness. For while both translators and spouses were once bound by contracts to love, honour, and obey, and while both inevitably betray, the current questioning of the possibility and desirability of conscious mastery makes that contract seem deluded and exploitative from the start. But what are the alternatives? Is it possible simply to renounce the meaning of promises or the promise of meaning?

Fortunately, I must address translation, not matrimony. Yet the analogy between the two is extremely far-reaching. It might, however, seem that the translator ought, despite or perhaps because of his or her oath of fidelity, to be considered not as a duteous spouse but as a faithful bigamist, with loyalties split between a native language and a foreign tongue.

(cited Graham 1985: 142-143)

This bigamist, she concludes, is 'doubly unfaithful, but in such a way that he or she must push to its utmost limit the very capacity for faithfulness (Graham 1985: 143). And this brings me to the next contrastive pair.

\section{Source or target}

One of Pacial's own targets, Jean-René Ladmiral has distinguished between the sourciers (translators facing towards the source text, language or author, conceiving their duty or success in relation to that commitment) and the ciblistes (those facing towards the target language and readership). In most cases, one imagines, a translator is doing both: they spend their time sweating over the source text, trying to 'get it right' in both detail and flow in relation to style, wording and presumed intention; but of course they do this with the aim of producing a piece of target-language text which will have the cardinal virtue of 'equivalence' — this term has replaced the older notions of 'accuracy' or fidelity — not simply 'saying the same thing' (whatever that might mean) but rather by doing the same job for a readership living here and now, and maybe in the future, to the presumed target readership of the author in 'that' time and 'that' place. A translation may be a murder but it is at the same time an attempt at resurrection. So the translator is inevitably facing both ways, and without the complicated secrecy of the more traditional bigamist.

Here is an example of what cibliste thinking can reveal: this target-based translation is actually not a translation at all. When the Americans left Vietnam in 1973 they set about the business of 'Vietnamization' - preparing the local population to take over roles that had recently been played by US military. Among these were technological jobs which had used English-language manuals; but when they began a translation of these manuals it quickly became clear that rendering the text from one language to another would not serve the purpose of addressing the needs of people with a different level or type of training. Starting from the source text may have seemed quicker and simpler; but in this instance 'the role of the source language text is merely that of a convenient help for 
composing a receptor language text, not of a model to be faithfully reproduced'. Thus, according to Ernst-August Gutt, who works in 'relevance theory', 'the more relevant the sociocultural differences are to the communication act, the less successful translation will turn out to be' (Gutt 1991: 62).

\section{Translator or translation}

Many translation theorists point out how different it is to consider translation in relation to the person doing the job (translator-based) or in relation to the outcome produced or intended (translation-based). I will come in a moment to what I think is the key difference between these two, the bilingual or monolingual position. Most often the distinction is described as that between 'process' and 'product'. On this contrast I shall look at a multiple translation.

In his discussion of Walter Benjamin's canonical essay Die Aufgabe des Übersetzers [The Task of the Translator] (written 1923, published 1955) — itself fiendishly difficult to translate or even understand, as many scalps have shown — Derrida notes:

Dès son titre - et pour l'instant je m'y tiens — Benjamin situe le problème, au sens de ce qui précisément est devant soi comme une tâche, comme celui du traducteur, et non de la traduction (ni d'ailleurs, soit dit au passage et la question n'est pas négligeable, de la traductrice).

(Derrida, in Graham 1985: 223)

[Already in his title — which is what I am looking at for the moment — Benjamin locates the problem, in the sense of what precisely lies before one as a task to be solved, as being that of the [male] translator — not of the translation (nor indeed — let's note in passing, but the question is not a negligible one - of the female translator) $].^{3}$

For Benjamin the translator should carry out the task with no sense of obligation to any imagined reader, for he [sic] owes his loyalty to an ideal of 'die reine Sprache' [pure language] (1972: 19; 1973: 80) or 'dieser wesenhafte Kern' [this [essential] nucleus] (1972: 15; 1973: 75$)^{4}$, which itself is strictly untranslatable. But, as Derrida notes, if this seeming mix of practicality and idealism evades a question of the gender habitually assigned to the text it also removes the actual bodiedness of the act of translation - in French, like German, a translation can only be feminine but a translator must be either a traducteur or a traductrice. And this leads to my last contrastive pair — the very different positions of the translator and the target reader in relation to language knowledge.

\section{$\mathrm{Bi} /$ multilingual or monolingual}

To my surprise - perhaps it is too obvious, but that is rarely a problem with theory - no one seems to raise the fundamental contrast between the position of the bi/multilingual person and that of the monolingual. Translators are always bi- or multilingual whereas the

3 The translation given is my own but, inevitably unsatisfied with it, I looked at that of Joseph Graham in the same volume, which I offer as a still less satisfying alternative: "From the very title — and for the moment I stay with it - Benjamin situates the problem, in the sense of that which is precisely before oneself as a task, as the problem of the translator and not that of translation (nor, be it said in passing, and the question is not negligible, that of the translatoress)" (Graham 1985: 179).

4 Here I have amended Zohn's translation. 
people they are writing for are in principle and generally in actuality monolingual ${ }^{5}$. This is surely the fundamental paradox of the whole activity: you are creating a product that hides not just its origin but the very practice that has brought it into being — your labour. It is actually not so much invisibility as something more like suicide; or, to use another metaphor, it is the paradoxical state of creating a person who will be not of unknown father but of unknown mother ${ }^{6}$. And this is indeed a part of the feminisation of translation, not just as a profession but as a principle.

To be multilingual or monolingual is a political difference; it belongs in the burgeoning area of postcolonial translation theory but is in principle larger than it ${ }^{7}$. For the more languages one knows the lower one's status. Servants and wives need to speak at least two idiolects; and migrant peoples are always seen as lacking the key monolingual skills that their hosts take for granted: they are suspect by reason of their greater knowledge. Ignorance is power. This is not the place to discuss the current dominance of the English language and the linguaphobia of many of its native speakers; here I want to relate it to the peculiarity of the relationship between translation as an activity and a theory and translation as an outcome.

When we theorise about translating we are always looking at a relation of plurality: the task or source-text, the person solving the series of knots and booby-traps that is the job in hand, and the general issues of a specific or global relation between languages. But this is nothing to the person we are actually addressing in the act of service we are engaged upon. S/he is someone who cannot judge if we have done it well or badly; who is, in other words, dependent on us to have cooked the perfect soufflé, danced the perfect ballet, because they will never see the eggs or blisters that preceded their reading experience. Only if the translation is so bad that it sounds like nothing known in the target language - and often not even then: remember Benjamin's approving citation of Rudolf Pannwitz who says "Our translators, even the best ones, proceed from a wrong premise. They want to turn Hindi, Greek, English into German instead of turning German into Hindi, Greek, English" (Benjamin 1973: 80) — is anything likely to impinge. A recent development in translation studies is 'prismatic' translation, which seeks to restore the plurality of translation in the product or its study; and there is some brilliant new work in this field such as Twin Spin, in which a set of Shakespeare sonnets are rendered into crazy German by Ulrike Draesner and back into even crazier English by Tom Cheesman. But in the main a reader of literature or modes d'emploi wants to find out what the characters did next or how to get the appliance working, and not to ponder how it reached them in this form.

5 When I gave the paper on which this essay is based at the 2016 Oxford Translation Day, an audience member pointed out that this difference is relative rather than absolute: translators must know more than one language, but they will also often be readers of translations from the many other languages which they do not know.

6 On this significant and far from rare phenomenon, see Maclean 1994.

7 Thus, although it may map most readily on to the particular neocolonial hegemony of English in our day, it is not exclusive to it: French, Portuguese and other languages will have had the same effect in their colonial spaces. And, as I argue above, it is larger even than colonialism, since any disadvantaged class providing services to a more advantaged one will need to speak several tongues. 
Monolingual readers of European theory in English will never know how badly they are abused by translations that render tout se passe comme si [it is as if] as 'everything happens as if', or the almost ubiquitous 'feminine' for the French féminin (which normally simply means 'female': that is, sex, not gender), which has had far-reaching and permanent effects, none of them good. Or again, there is the translation of unbeimlich as 'unhomely', which even the most cursory reading of Freud's essay in Strachey's translation should make impossible.

As a multilingual serving the needs and demands of the monolingual, the translator is like the three-year-old girl who is told that if her older brother cannot do up his shoe-laces, as she can, she should get down and help him. No wonder then that translators are endlessly fascinated by what they do, how hard it is, which bits drove them most mad, or the dire consequences of mistranslations - because if they do not talk about it no one else will. But no wonder either that it is infinitely easier to see what is wrong with someone's translation decisions than it is to do any better.

With this I am going to turn from translation in general to translation of psychoanalysis in particular. I will cite many gripes against the Standard Edition, in both broad and specific terms, and believe me I will only scratch the surface of that iceberg.

\section{Translating Freud}

On two occasions in the last thirty years I have run international events examining the question of the translation of Freud. The first was a conference in 1986, Freud in London, which included a panel on the subject and was followed by a coedited volume, Frend in Exile, in 1988. The five contributors to the book section on translation reappear in the discussion that follows, all the more as one of them, Darius Gray Ornston, edited an important collection of his own, Translating Freud, in 1992. The other event was part of a Core Programme I ran at the Institute of Germanic \& Romance Studies in 2006-08, called Psychoanalysis and the Arts and Humanities: a multilingual perspective. It brought together analysts, academics and artists, involved six languages and included six conferences, eight seminar series and numerous publications. The opening conference, held in November 2006, was called Freud in Translation, Freud in transition, and started with a discussion of the different translations of a number of psychoanalytic keywords, followed by a set of workshops on the opening paragraphs, in a variety of translations, of Freud's essay 'Der Dichter und das Phantasieren' (1908).

The keywords in five languages are below:

Table 1. From Freud in Translation, Freud in Transition, IGRS 2006

\begin{tabular}{|l|l|l|l|l|}
\hline \multicolumn{1}{|c|}{ GERMAN } & \multicolumn{1}{|c|}{ ENGLISH } & \multicolumn{1}{c|}{ FRENCH } & \multicolumn{1}{c|}{ ITALIAN } & SPANISH \\
\hline Besetzung & cathexis & investissement & $\begin{array}{l}\text { carica/ } \\
\text { investimento }\end{array}$ & carga \\
\hline das Unheimliche & the uncanny & l'inquiétante étrangeté & il perturbante & lo siniestro \\
\hline Ich, Es & ego, id & moi, ça & io, es & yo, ello \\
\hline
\end{tabular}




\begin{tabular}{|l|l|l|l|l|}
\hline \multicolumn{1}{|c|}{ GERMAN } & \multicolumn{1}{|c|}{ ENGLISH } & \multicolumn{1}{|c|}{ FRENCH } & \multicolumn{1}{c|}{ ITALIAN } & \multicolumn{1}{c|}{ SPANISH } \\
\hline nachträglich & deferred & après-coup & posteriore & posterior \\
\hline seelisch/psychisch & psychic/al & psychique & $\begin{array}{l}\text { psichico/ } \\
\text { mentale }\end{array}$ & psíquico \\
\hline Trieb & instinct/drive & pulsion & istinto & instinto \\
\hline Übertragung & transference & transfert & $\begin{array}{l}\text { transfert/ } \\
\text { traslazione }\end{array}$ & trasferencia \\
\hline Verdrängung & repression & refoulement & rimozione & represión \\
\hline
\end{tabular}

It is worth noting that there are two translations of the essay into Spanish - one by a Spanish translator, the other by an Argentinean; at the time of the conference there were no fewer than three French ones and there are now two English ones; here, as a sample of legitimate variety, are the titles of the latter five versions:

La création littéraire et le rêve éveillé. (Freud [Bonaparte and Marty] 1933)

Le créateur littéraire et la fantaisie. (Freud [Féron] 1985)

Le créateur littéraire et l'activité imaginative. (Freud [Cambon] 2001)

Creative writers and day-dreaming. (Freud [Strachey] 2001c)

The Creative Writer and Daydreaming. (Freud [McLintock] 2003)

From here I will focus on the translation of Freud into English. This task was begun, of course, in his own lifetime, and continued in that of his daughter and legatee, Anna.

In 1909, A. A. Brill translated 'Selected Papers on Hysteria' and he did a number of other translations in the next thirty years, notably The Interpretation of Dreams (1913); at the time Freud congratulated him on his achievement (Ornston 1998: 214), but later he wrote in a letter that he considered Brill's translations 'more conscientious than beautiful' (Ornston 1998: 215). In the same year Freud, together with Jung, gave a series of lectures at Clark University in the USA, translated by H. W. Chase (Steiner 1998: 183). Freud's attitude to the USA was broadly dismissive, not least because of the restriction there of psychoanalytic practice to medical doctors: when writing to Ernest Jones about the latter's wish to create a standard edition and glossary, his view was that 'the world will go on very much the same whether the Americans get a good or bad source book for my writings' (cited Ornston 1998: 212). According to Riccardo Steiner, the standardization of Freud in English was a Britishimperialist conspiracy originating with Jones - a Welshman, but very much an Anglophone one — following a meeting in Vienna in 1908. At this meeting, Freud suggested some key terms such as 'repression' for Verdrängung (Steiner 1998: 183) and seemingly approving the use of the kind of Latin and Greek terms for which Strachey has been so maligned.

After the First World War, Jones announced his intention to standardize Freudian technological terms in English and in 1924 he published the official glossary, compiled with a committee that included Freud himself, Joan Riviere and James and Alix Strachey; 
Steiner comments: 'although Freud did not explicitly agree, he did not disagree' (Steiner 1998: 187). It is noteworthy that in this 1924 Glossary, about ' 90 per cent of the terms had been coined by Brill and Jones as early as 1908-10' (Steiner 1998: 188). But Freud certainly favoured Strachey over Jones (who was jealous of his analysis of both Stracheys, in a way typical of all F's rivalrous 'children').

Two more of Freud's remarks on the question of being translated into English, both reported by Jones, give a sense of his fairly relaxed attitute: 'I'd rather have a good friend than a good translator' (cited Bettelheim 1985: 79) and 'Unfortunately The Interpretation of Dreams is not translatable and would have to be made anew in every language, which might be a worthwhile job for an Englishman' (cited and trans. Junker in Ornston 1992: 62).

James Strachey is of course the author of the Standard Edition, though it is often overlooked that he was working in a team alongside three women: his wife Alix, Anna Freud and Angela Richards. This translation, with its massive editorial framework and thorough cross-references, has been used as a model by readers of every language, including German; and Strachey's own notes, as we shall see, often display scruples over his translation choices; but in the last thirty years it has come in for waves of criticism ${ }^{8}$, described variously as 'heroic' (IX), and 'elegant' (Mahony 1987: 34), yet as also 'doctoring up' (Mahony 1987: 42), 'translating out' (Mahony 1987: 43), 'stiff and masterly' (200) and of course over'scientific' (Bettelheim 1985: 5), in its treatment of Freud's German, which itself is considered to be 'pliable' (104), 'free-floating' (Mahony 1987: 36), 'versatile' (97), 'stereophonic' (Mahony 1987: 39), 'dialogic' (Junker 59), ‘crazy’ (106), ‘demonic' (111), 'protean’ (112), 'polyphonic' (Holder 1998: 82, 85), 'enchanting' (199), 'skittish' (198) and having 'rhetorical verve' (Webber 2002: XXIV). Strachey is strafed especially for his choice of certain 'technical terms'. In the next section of this essay I will focus on the most debated of these terms.

\section{'Trieb', translated as 'instinct'}

This is one of the most contentious of Strachey's choices, but also one that has since been resolved. In his 'Notes on some technical terms whose translation calls for comment' (Freud [Strachey] 2001a: XXIII-XXVI) he devotes a page and a half of small print to it, beginning: 'My choice of this rendering has been attacked in some quarters with considerable, but, I think, mistaken severity. The term almost invariably proposed by critics as an alternative is "drive" (XXIV). His rather irritable objection is that "drive, used in this sense, is not an English word and, as I have explained in my preface, this translation aims at being a translation into English' (XXIV-XXV), a jibe at critics who are native Germanspeakers. Arguing that Freud uses Trieb in many different ways — 'it is not the business of a translator to attempt to classify and distinguish between Freud's different uses of the word. This job can safely be left to the reader, provided only that the same English word is invariably used for the German original' (XXV) - though this is a rule we often find Strachey breaking — he ends: 'The only rational thing to do in such a case seems to me to be to choose an obviously vague and indeterminate word and stick to it' (XXV). And where Freud actually uses 'Instinkt' he will put a footnote.

8 The epithets cited here on Strachey and Freud are all derived, unless otherwise noted, from Ornston 1992. 
Since then, of course, 'drive' used as a noun has successfully stuck and is universally preferred, mainly because 'instinct' implies too much animality — this is how Freud uses it. As the Keywords Grid shows, French has gone for the closer translation, while Italian and Spanish follow Strachey.

\section{'Besetzung', translated as 'cathexis'}

The rest of my examples are criticised for introducing Latin and Greek terms, with the implicit aim of making the terms more technical and medical. As we have seen, Freud did not fundamentally object to this, but it does contradict his own creatively free-flowing style. The value of the word Besetzung and its derivatives is its simplicity: it is an everyday term for 'occupation' or 'possession', used in contexts such as military actions, casting roles in the theatre or finding a toilet engaged. Strachey inserts a footnote in an Appendix to 'The neuro-psychoses of defence', titled 'The emergence of Freud's fundamental hypotheses'; here, he confesses that 'Freud, who disliked unnecessary technical terms, was unhappy when in 1922 the present editor, in the supposed interests of clarity, introduced the invented word "cathexis" (from the Greek (...) chatechein, to occupy) as a translation. He may perhaps have become reconciled to it in the end, since it is to be found in his original manuscript of his Encyclopaedia Britannica article (1926)' (Freud [Strachey] 2001b: 63n). Joan Riviere opted for 'investment' — as do the French and Italian terms, but in those languages the dominant financial meaning in English is avoided. In this she is followed by Graham Frankland, though he admits that "charge" is an equally strong contender, and one that has the additional merit of resonating with the 'electricity' imagery so fundamental to Freud's metapsychology' (Frankland 2005: XXIII) — and the same goes for the Spanish and alternative Italian terms. Joyce Crick also chooses 'the (not unproblematic) "charge" (Crick 2002: XXXI) and David McLintock follows her, commenting that readers are unlikely to have come across 'cathexis' or 'cathect' — though he makes the point that they are used in Strachey's way in the Oxford English Dictionary of 1989. It is Andrew Webber who regrets the 'economic' connotations of 'investment' but he uses it nonetheless because of — and this is a thread that particularly interests me the extensive repertory of economic metaphors that Freud adopts in order to figure the dynamic system of the drives as conduits of libidinal interest' (Webber 2002: XXV) ${ }^{9}$.

\section{'Das Ich, das Es', translated as 'ego, id'}

This is another famously contentious decision. A glance at the grid reveals that English is the only one of the four target languages which does not follow Freud's lead in representing the three elements of the 'structural model' of the psyche by the ultra-simple nouns derived from 'I' and 'it'. Bruno Bettelheim, who abhors the 'soulless' scientism of Strachey, describes 'ego' and 'id' as 'cold technical terms, which arouse no personal associations' (Bettelheim 1985: 53). Ornston steps in to defend Strachey by noting: 'we now know that

9 This whole thread in Freud, which appears from his earliest writings and becomes known as his 'economic theory', is actually based on a hydraulic system of flows and blocks (membranes, channels etc) which may be disguised under financial or military terms, metaphors from electricity or physics, an alphabet soup of algebraic lettering or a series of rather cute 'cartoons' (as Ornston calls them), but essentially, in my view, it is a 'hydraulic theory [based on] the supposedly mechanical processes of a man's body' (Segal 1998: 1ff). 
the Stracheys and John Rickman vigorously opposed Jones's choices for The Ego and the Id, and we know that Jones turned the tide; but we do not know how or why' (Ornston 1988: 202). Among the recent re-translators of Freud, Shaun Whiteside raises a practical problem

in early drafts of this book (...) I experimented with 'the I' and 'the It', as a way of deliberately distancing the translation from the Standard Edition, but discovered that all sorts of unexpected problems arose. What, for example, is the plural of 'the It'? 'Its'? or of 'the I', or the 'above-I'? Finally, and not without regret, I had to concede that Strachey and his team had reached an ingenious solution to an almost intractable problem. (Whiteside 2005: XXXI-XXXII)

But, to add a final twist, Ornston cites a curious anti-semitic objection in a letter from Strachey to his wife 'in the midst of this dispute' (Oct 1924):

The little beast (...) is really most irritating (...). They want to call 'das Es' 'the Id'. I said I thought everyone would say 'the Yidd'.

So Jones said there was no such word in English: "There's "Yiddish", you know. And in German "Jude". But there is no such word as "Yidd".

'Pardon me, doctor. "Yidd" is a current slang word for a Jew'.

'Ah! A slang expression. It cannot be in very widespread use then'.

Simply because the l. b. hasn't ever heard of it. (Ornston 1992: 108)

\section{'Seele, seelisch', translated as 'psyche, mental'}

This term is the leading issue in Bruno Bettelheim's impassioned polemic Freud and Man's Soul (1983). Bettelheim was born in Vienna in 1903 though he had lived in the USA since 1939. As I have shown, he was inveighing against both Strachey's scientific choices and the exclusion from the American psychoanalytic establishment of non-medically qualified people. He shows how often Freud uses Seele [soul] in contexts where Strachey translates it as 'psyche' (which of course means 'soul' in Greek) or often, in adjectival or compound form, as 'mental'. Part of the problem is that Freud uses Seele and Psyche almost interchangeably. To Bettelheim, 'such substitutions are particularly misleading because in German the word Seele and seelisch have even more exclusively spiritual meanings than the word "soul" has in present-day American usage' (Bettelheim 1985: 81). But Ornston disagrees: 'although the English "soul" has stayed spiritual, by Freud's time die Seele had a scientific use: Seelenkunde and Seelenlehre meant "psychology" (Ornston 1992: 62) ${ }^{10}$. Intervening on this debate ten years later, Louise Adey Huish slices the Gordian knot entirely: "where Strachey consistently translates Seele and its cognates in a very narrow sense as "mind" or "mental" I have opted for the adjective "inner", translating Seelenleben, for example, as "inner life"" (Adey Huish 2002: XXXI). Which could, I suggest, be called a happy ending ${ }^{11}$.

10 For an excellent serious psychoanalytic account of the soul one cannot do better than Otto Rank 1998 [1930]).

11 In an email dated 22 February 2016, the eminent Russian-English translator Robert Chandler commented to me: 'I was interested to read Louise Adey Huish translating Seelenleben, for example, as "inner life". Very good indeed. What to do with "soul" and its cognates is a constant problem for translators from Russian'. 


\section{The fact...}

One issue is a curiosity I had not thought about before. In German (and indeed in French) one can introduce an idea simply by a daß or a que, in contexts where English more fluently opens with 'the fact that...' Ornston throws this at Strachey's head: '[he] begins his fifth chapter [of Beyond the Pleasure Principle] with "The fact that...", although Freud does not imply that he is describing or accounting for any facts' (Ornston 1992: 10). I confess it had not occurred to me that this implies the existence of an object called a fact, something quasi-concrete that did not exist in the original. Joyce Crick finds ways of avoiding this by turning sentences around, so that 'readers can be assured that when the word "fact" occurs (not a few times) it is — with one insoluble exception — Freud's own, and not thrust on him out of translator's convenience' (Crick 2002: XXXIV-XXXV).

So - where have these adventures in Translationland taken us? Some pages ago, I quoted George Steiner saying that translation starts with an act of trust. I want to end by revisiting this with the addition of a feminist perspective. I have hinted a few times at the feminine/feminised status of translation. Might this be because most translators are women, or because the grammatical gender of 'traduzione', 'traduction' or 'Übersetzung' appears to invite crude analogies of the sexiness of beauty or fidelity fantasized as female? Or might it be because translation embodies the paradox of the multi-skilled serving the mono-skilled in a way that is ideally 'shy', 'humble' or 'invisible'? When Steiner talks of 'trust' he means a philosophical trust in 'an as yet untried, unmapped alternity of statement' (cited Venuti 2000: 186). I agree with him. But experience suggests that translation — and the 'task of the translator' - consists above all in an act of self-trust: trust in one's knowledge of the sourcetext language, to be sure, though this is repeatedly shored up with dictionaries, consultation, parallel versions etc; but above all, trust in the maternity of what we call our mother-tongue. 


\section{Bibliography}

Adey Huish Louise (2002), Translator's Preface [in:] S. Freud, The 'Wolfman' and Other Cases, Penguin, London.

Anzieu Didier (1990), A Skin for thought, trans. Daphne Nash Briggs, Karnac, London.

- (1991 [1986]), Une Peau pour les pensées, Apsygée, Paris.

- (1995 [1985]), Le Moi-peau, Dunod, Paris.

- (2016), The Skin-ego, transl. Naomi Segal, Karnac, London.

Bassnett Susan (2002), Translation Studies, $3^{\text {rd }}$ edn., Routledge, London-New York.

Benjamin Walter (1972 [1955]), Die Aufgabe des Übersetzers, „Gesammelte Schriften” IV/1, Suhrkamp.

- (1973 [1955]), The task of the translator, transl. Harry Zohn [in:] Illuminations, ed. H. Arendt, Fontana, London.

Bettelheim Bruno (1985 [1983]), Freud and Man's Soul, Fontana, London.

Birksted-Breen Dana (2010), Is translation impossible?, „International Journal of Psychoanalysis", 91.

Crick Joyce (2002), Translator's Preface [in:] S. Freud, The Joke and its relation to the Unconscious, Penguin, London.

Draesner Ulrike, Cheesman Tom (2016), Twin Spin: 17 Shakespeare Sonnets, Taylor Institution Library, Oxford.

Forrester John (1990), The Seductions of Psychoanalysis: Freud, Lacan and Derrida, Cambridge UP, Cambridge.

Frankland Graham (2005), Translator's Preface [in:] S. Freud, The Unconscious, Penguin, London.

Freud Sigmund (1933), La création littéraire et le rêve éveillé [in:] Essais de psychanalyse appliquée, transl. M. Bonaparte, M.E. Marty, Gallimard, Paris.

- (1985), Le créateur littéraire et la fantaisie [in:] L'inquiétante étrangeté et autres essais, transl. B. Féron, Gallimard, Paris.

- (1999 [1941]), Der Dichter und das Phantasieren [1908] [in:] Gesammelte Werke, Band VII, eds. A. Freud et al., Imago-Fischer, London-Frankfurt.

- (2001a), Pre-psychoanalytic publications and Unfinished Drafts (1886-1899), eds. and transl. J. Strachey et al., Standard Edition vol. I, Vintage, London.

- (2001b [1906, 1962]), Early psychoanalytic publications (1893-1899), eds. and transl. J. Strachey et al., Standard Edition vol. III, Vintage, London.

- (2001c [1908, 1959]), Creative writers and day-dreaming [in:] Jensen's 'Gradiva' and other works (1906-1908), eds. and transl. J. Strachey et al., Standard Edition vol IX, Vintage, London.

- (2001d), Le créateur littéraire et l'activité imaginative [in:] Das Unheimliche / L'inquiétante étrangeté, transl. F. Cambon, Gallimard Collection Folio bilingue, Paris.

- (2003), The Creative Writer and Daydreaming [in:] The Uncanny etc, ed. A. Phillips, transl. D. McLintock, Penguin, London.

Difference in Translation (1985), ed. J.F. Graham, Cornell UP, Ithaca-London.

Gutt Ernst-August (1991), Translation and Relevance, Blackwell, Oxford-Cambridge MA.

Hatim Basil, Mason Ian (1997), The Translator as Communicator, Routledge, London-New York. Holder Alex (1988), Reservations about the Standard Edition, Timms-Segal.

Junker Helmut (1988), On the difficulties of retranslating Frend into English, Timms-Segal. 
Maclean Marie (1994), The Name of the Mother: Writing Illegitimacy, Routledge, London-New York.

Mahony Patrick J. (1987), Freud as a Writer, Yale UP, New Haven-London.

McLintock David (2003), Translator's Preface [in:] S. Freud, The Uncanny, Penguin, London.

Newmark Peter (1981), Approaches to Translation, Pergamon Press, Oxford.

Ornston Darius Gray Jr. (1988), How standard is the 'Standard Edition'? 'Timms-Segal.

Ornston Darius Gray Jr., ed. (1992), Translating Freud, Yale UP, New Haven-London.

Pacial Claire (2014), Du danger certaines analogies en traductologie (sur les belles infidèles et le viol de la langue), http://languesdefeu.hypotheses.org/686 [access: 29 September 2016].

Phillips Adam (2007), After Strachey, "London Review of Books" 29: 19 (4 Oct 2007), 36-38, http://www.lrb.co.uk/v29/n19/adam-phillips/after-strachey [access: 29 September 2016].

Picken Catriona, ed. (1989), The Translator's Handbook, $2^{\text {nd }}$ edn, Aslib, London.

Pines Malcolm (1988), The Question of Revising the Standard Edition, Timms-Segal.

Rank Otto (1998 [1930]), Psychology and the Soul, transl. G. Richter, J. Lieberman, Johns Hopkins UP, Baltimore-London.

Reddick John (2003), Translator's Preface [in:] S. Freud, Beyond the Pleasure Principle and Other Writings, Penguin, London.

Segal Naomi (1998), André Gide: Pederasty and Pedagogy, OUP, Oxford.

- (2009), Consensuality: Didier Anzieu, gender and the sense of touch, Rodopi, Amsterdam-New York.

Shakespeare William (1951 [1590-1597]), A Midsummer Night's Dream [in:] The Complete Works (Tudor Edition) ed. P. Alexander, Collins, London-Glasgow.

Steiner Riccardo (1998), 'Die Weltmachtstellung des Britischen Reichs': Notes on the term 'standard' in the first translations of Freud, Timms-Segal.

Timms Edward, Segal Naomi (1998), Freud in Exile: Psychoanalysis and its Vicissitudes, Yale UP, New Haven-London.

Underwood James Amery (2005), Translator's Preface [in:] S. Freud, Mass Psychology and Other Writings, Penguin, London.

Venuti Lawrence, ed. (2000), The Translation Studies Reader, Routledge, London-New York.

Webber Andrew (2002), Translator's Preface [in:] S. Freud, The Schreber case, Penguin, London.

Whiteside Shaun (2005), Translator's Preface [in:] S. Freud, On Murder, Mourning and Melancholia, Penguin, London. 